\title{
Aktivitas Antioksidan Tepung Pisang Goroho (Musa spp) yang Direndam dengan Beberapa Rempah-Rempah
}

\author{
Iqra. U. Kanopaa*, Lydia I. Momuata, Edi Suryantoa
}

aJurusan Kimia, FMIPA, Unsrat, Manado

\section{KATA K UNCI}

Rempah-rempah

Musa, spp

aktivitas antioksidan

\section{KEYW OR D S}

\section{Spices}

Musa, spp

antioxidant activity

\begin{abstract}
A B S T R A K
Penelitian ini bertujuan mempelajari pengaruh perendaman pisang goroho dengan ekstrak rempah-rempah terhadap aktivitas antioksidan tepung pisang goroho. Ekstrak rempah-rempah (daun cengkeh, daun salam, rimpang kunyit, biji pala, rimpang jahe, daun sereh, kayu manis, merica putih, rimpang lengkuas dan buah andaliman) diperoleh dengan maserasi menggunakan pelarut etanol. Selanjutnya, pisang goroho direndam selama 60 menit dalam ekstrak rempah-rempah, lalu tepung pisang goroho yang dihasilkan dianalisis kandungan total senyawa fenolik dan aktivitas penangkal radikal bebas 1,1-diphenyl-2-picrylhidrazil (DPPH). Hasil penelitian menunjukkan bahwa kandungan senyawa fenolik dan aktivitas antioksidan tertinggi dimiliki oleh tepung pisang yang direndam dengan ekstrak daun salam dan yang paling rendah terdapat pada tepung yang direndam dengan ekstrak merica putih. Penelitian ini menyimpulkan bahwa perendaman pisang goroho dengan ekstrak rempah-rempah mampu meningkatkan aktivitas antioksidan dari tepung pisang goroho.

\section{A B S T R A C T}

The objective was to determine the study the effect of immersion the banana goroho with spice extracts on the antioxidant activity of banana flour goroho. Extracts of spices (clove leaf, bay leaves, turmeric, nutmeg, ginger, lemon grass leaves, cinnamon, white pepper, ginger rhizome and fruit andaliman) obtained by maceration using ethanol solvent. Furthermore, bananas goroho immersed for $60 \mathrm{~min}$ in extracts of spices and banana flour produced goroho analyzed total phenolic content and free radical antidote activity 1.1-diphenyl-2-picrylhidrazil (DPPH). The results showed that banana flour, marinated with spices extracts contain phenolic and the highest antioxidant activity present in the extract of flour banana leaves and the lowest found in extracts of white pepper. This study concluded that the immersion banana goroho with spice extracts can increase the antioxidant..
\end{abstract}

\section{Pendahuluan}

Pisang merupakan tanaman yang berkembang di Indonesia dan juga memiliki beraneka macam jenis dan bentuknya. Selain itu pisang merupakan sumber karbohidrat dan vitamin. Pisang goroho (Musa spp) merupakan tanaman khas dari Sulawesi Utara. Pisang goroho juga dijadikan makanan utama penderita diabetes militus. Banyaknya kandungan gizi dan manfaat dari tepung pisang memungkinkan menambah produksi tepung pisang.

Namun, permasalahan dalam pembuatan tepung pisang yaitu terjadinya reaksi pencoklatan. Pada umumnya buah pisang mudah mengalami pencoklatan setelah dikupas karena mengandung enzim polifenolase sehingga dalam membuat tepung sering dilakukan perendaman buah pisang dalam larutan natrium metabisulfit untuk mencegah pencoklatan. Namun demikian, bahan tersebut tidak mampu meningkatkan kandungan fitokimia yang bermanfaat bagi kesehatan. Berdasarkan Material Safety Data Sheet (MSDS) (2005), natrium metabisulfit dilaporkan bisa menyebabkan reaksi alergi pada orang yang sensitif sulfit.

Natrium metabisulfit yang tidak bermanfaaat bagi kesehatan bila digunakan pada bahan pangan

*Corresponding author: Jurusan Kimia FMIPA UNSRAT, Jl. Kampus Unsrat, Manado, Indonesia 95115; Email address: iqrautami@ymail.com

Published by FMIPA UNSRAT (2012) 
dapat diganti dengan senyawa lain yang bersifat antioksidan. Antioksidan adalah senyawa yang dapat mencegah oksidasi. Senyawa fenolik merupakan senyawa yang dapat mencegah oksidasi yang banyak terkandung dalam sayuran, buah-buahan rempahrempah.

Penelitian mengenai perendaman pisang goroho dengan lemon kalamansi telah dilakukan oleh Kiay et al. (2011), tetapi perendaman pisang goroho dengan ekstrak rempah-rempah sepengetahuan penulis belum pernah dilakukan. Perendaman dengan ekstrak rempah-rempah diharapkan dapat meningkatkan aktivitas antioksidan dari tepung pisang goroho mengingat rempah-rempah umumnya mengandung komponen bioaktif yang bersifat antioksidan. Rempah-rempah yang akan digunakan dalam penelitian ini ada sepuluh jenis yaitu: kayu manis, daun salam, lengkuas, kunyit, daun cengkeh, merica putih, daun sereh, andaliman, biji pala dan jahe.

\section{Metode}

\subsection{Bahan dan Alat}

Alat-alat utama yang digunakan dalam penelitian ini adalah vortex, Spektrofotometer UV-Vis Milton Roy 501, sentrifuge Clements 2000, oven dan desikator. Bahan-bahan yang digunakan dalam penelitian ini adalah 10 jenis rempah-rempah (daun cengkeh, daun salam, rimpang kunyit, biji pala, rimpang jahe, daun sereh, kayu manis, merica putih, rimpang lengkuas dan buah andaliman), buah pisang goroho yang diperoleh dari pasar lokal Manado. Bahan-bahan kimia yang digunakan yaitu aquades, aluminium foil, etanol $80 \%$, reagen Folin Ciocalteu 50\%, natrium karbonat 2\%, 1,1-difenil-2-pikrilhidrazil (DPPH).

\subsection{Metode Penelitian}

\subsubsection{Pembuatan Tepung Pisang Goroho}

Buah pisang goroho dikupas dari kulitnya, kemudian dipotong-potong hingga ketebalan $2 \mathrm{~mm}$, selanjutnya pisang direndam dalam larutan ekstrak rempah-rempah $(0,1 \%)$, selama 60 menit. Pada akhir perendaman potongan pisang goroho ditiris untuk menghilangkan airnya. Setelah air rendaman tidak menetes lagi, potongan pisang dikeringkan pada suhu $65{ }^{\circ} \mathrm{C}$ selama 9 jam. Potongan pisang yang telah kering digiling dengan alat penggiling sampai halus, lalu disimpan dalam kantong-kantong plastik.

\subsubsection{Ekstraksi Tepung Pisang Goroho}

Sebanyak satu gram tepung pisang goroho dimasukkan ke dalam tabung reaksi yang dilapisi aluminium foil untuk menghindari cahaya, kemudian diekstraksi selama 24 jam dengan $5 \mathrm{~mL}$ pelarut etanol $80 \%$, selanjutnya disentrifugasi (3000 rpm) selama 10 menit. Supernatannya ditepatkan kembali menjadi $5 \mathrm{~mL}$ dengan etanol 80\% sehingga diperoleh ekstrak tepung pisang goroho.

\subsubsection{Penentuan Kandungan Total Senyawa Fenolik}

Kandungan total senyawa fenolik ditentukan melalui uji Folin Ciocalteu (Conde, et al., 1997).
Larutan ekstrak rempah-rempah sebanyak 0,1 mL dimasukkan ke dalam tabung reaksi, lalu ditambah 0,1 $\mathrm{mL}$ reagen Folin Ciocalteu 50\%. Campuran tersebut divorteks selama 3 menit, lalu ditambah 2 $\mathrm{mL}$ larutan $\mathrm{Na}_{2} \mathrm{CO}_{3} 2 \%$. Selanjutnya larutan diinkubasi dalam gelap selama 30 menit. Absorbansinya dibaca pada $\lambda 750 \mathrm{~nm}$ dengan spektrofotometer. Hasilnya diplotkan terhadap kurva standar asam galat yang dipersiapkan dengan cara sama. Kandungan total fenol dinyatakan sebagai mg ekuivalen asam galat/kg ekstrak. Kurva kalibrasi dipersiapkan pada cara yang sama dengan menggunakan asam galat.

\subsubsection{Penentuan Aktivitas Penangkal Radikal Bebas DPPH}

Penentuan aktivitas penangkal radikal bebas dengan metode (Gaulejac dalam (Kiay, 2011) Sebanyak $2 \mathrm{~mL}$ larutan 1,1-difenil-2-pikrilhidrazil (DPPH) 0,2 Mm dalam etanol ditambahkan 0,5 mL ekstrak rempah-rempah. Tingkat berkurangnya warna dari larutan menunjukkan efisiensi penangkap radikal. Lima menit terakhir dari 30 menit, absorbansi diukur dengan spektrofotometer pada $\lambda 517 \mathrm{~nm}$. Aktivitas penangkap radikal bebas dihitung sebagai persentase berkurangnya warna DPPH dengan menggunakan persamaan:

$$
\begin{aligned}
& \text { Aktivitas penangkal radikal bebas } \\
& =\left(1-\frac{\text { absorbansi sampel }+ \text { kontrol }}{\text { absorbansi kontrol }}\right) \times 100 \%
\end{aligned}
$$

\section{Hasil dan Pembahasan}

\subsection{Rendemen Tepung Pisang Goroho}

Hasil rendemen dan kandungan total senyawa fenolik tepung pisang goroho dari perendaman 10 jenis ekstrak rempah-rempah disajikan pada Tabel 1.

Data pada Tabel 1 menunjukkan bahwa pisang goroho dengan perendaman ekstrak daun salam memiliki rendemen paling tinggi sedangkan rendemen paling sedikit terdapat pada ekstrak kayu manis. Ekstrak rempah dan lama perendaman berpengaruh pada rendemen tepung pisang goroho. Diduga karena komponen senyawa yang terdapat pada ekstrak rempah-rempah yang berbeda-beda yang terserap pada pisang goroho. Rendemen pisang goroho dengan perendaman ektrak rempah-rempah mengalami peningkatan melebihi jumlah rendemen kontrol 1 (hanya direndam dengan akuades) yaitu $33,31 \%$, peningkatan jumlah rendemen yang disebabkan oleh kandungan senyawa aktif yang terdapat pada sepuluh jenis ekstrak rempah-rempah terserap oleh pisang goroho.

\subsection{Kandungan Total Senyawa Fenolik}

Penentuan kandungan total senyawa fenolik dalam tepung pisang goroho dilakukan untuk mengetahui kandungan senyawa fenolik dalam tepung pisang goroho, dengan metode Folin-ciocalteu. Total senyawa fenolik dinyatakan sebagai asam galat $\mu \mathrm{g} / \mathrm{mL}$ ekstrak. Penggunaan Asam galat digunakan sebagai standar karena senyawa ini sangat efektif 
untuk membentuk senyawa kompleks dengan reagen folin-ciocalteu, sehingga reaksi yang terjadi lebih sensitif dan intensif. Metode analisis Folin-ciocalteu didasarkan pada kemampuan sampel untuk mereduksi reagen folin-ciocalteu yang mengandung senyawa asam fosfomolibdat-fosfotungstat, membentuk senyawa kompleks yaitu molibdenum tungstant yang berwarna biru. Semakin pekat intensitas warna menunjukkan kandungan fenol dalam ekstrak semakin besar (Julkunen-Tiito, 1985).

Tabel 1 - Rendemen dan Kandungan Total Senyawa Fenolik dari tepung pisang

\begin{tabular}{|l|c|c|}
\hline \multicolumn{1}{|c|}{ Perendaman ekstrak } & Rendemen $(\%)$ & Total senyawa Fenolik $(\mu \mathrm{g} / \mathrm{mL})$ \\
\hline Kayu Manis (KM) & 36,14 & 17,65 \\
\hline Daun salam (DS) & 36,40 & 33,57 \\
\hline Lengkuas (LK) & 36,26 & 19,39 \\
\hline Kunyit (KY) & 38,00 & 28,47 \\
\hline Daun Cengkeh (DC) & 37,85 & 20,31 \\
\hline Merica Putih (MP) & 36,54 & 14,18 \\
\hline Daun Sereh (DH) & 37,19 & 18,27 \\
\hline Andaliman (AM) & 37,44 & 26,43 \\
\hline Biji Pala (BP) & 38,88 & 19,29 \\
\hline Jahe (JH) & 37,17 & 18,16 \\
\hline Kontrol 1 (K1) & 33,31 & 7,04 \\
\hline Kontrol 2 (K2) & - & 3,98 \\
\hline
\end{tabular}

Ket:K1= pisang goroho yang direndam dalam aquades , K2= tepung pisang kepok komersial

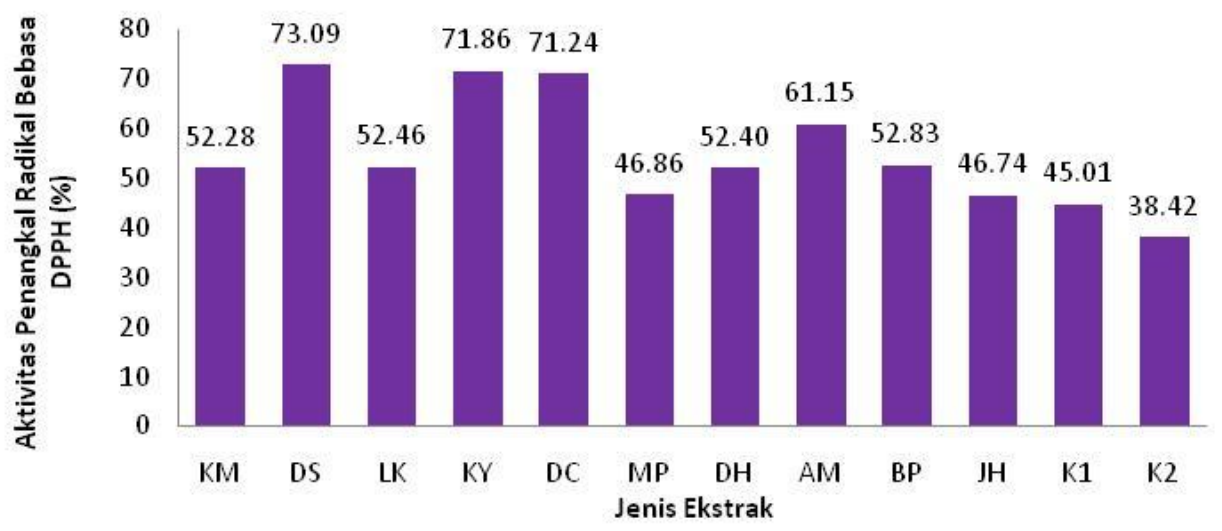

Gambar 1 - Aktivitas Penangkal Radikal Bebas DPPH dari Tepung Pisang Goroho yang Direndam dengan Ekstrak Rempah-Rempah (:K1= pisang goroho yang direndam dalam aquades , $\mathrm{K} 2=$ tepung pisang kepok komersial)

Kandungan senyawa fenolik pada tepung pisang dapat dilihat pada Tabel 1, dengan kandungan yang paling tinggi adalah tepung pisang yang direndam dengan ekstrak daun salam diikuti kunyit, cengkeh, andaliman, lengkuas, biji pala, daun sereh, kayu manis, jahe, dan merica putih. Faktor ini diduga karena pengaruh dari komponen senyawa yang terkandung didalam ekstrak rempah rempah tidak terserap secara baik oleh pisang goroho.

Kontrol 1 memiliki kandungan total senyawa fenolik 7,04 $\mathrm{\mu g} / \mathrm{mL}$ sedangkan kontrol 2 (tepung pisang kapuk komersil) memiliki kandungan 3,98 $\mu \mathrm{g} / \mathrm{mL}$. Total senyawa fenolik pada kedua kontrol yang relatif rendah menunjukkan perendaman pisang goroho dengan ekstrak rempah-rempah mampu meningkatkan kandungan fenolik dari tepung pisang goroho, yang kemungkinan dikarenakan rempahrempah mengandung komponen bioaktif yang bersifat sebagai antioksidan.

\subsection{Uji Aktivitas Antioksidan Penangkal Radikal Bebas DPPH}

Kandungan aktivitas penangkal radikal bebas DPPH dari tepung pisang goroho hasil rendaman ekstrak rempah-rempah $0,1 \%$ selama 60 menit disajikan dalam Gambar 1.

Dari Gambar 1 dapat dilihat bahwa persentasi aktivitas penangkal radil bebas DPPH tepung pisang yang paling tinggi adalah tepung pisang yang direndam dengan ekstrak daun salam sebanyak $73,09 \%$, diikuti kunyit sebanyak $71,86 \%$, daun cengkeh sebanyak 71,24\%, andaliman sebanyak $61,15 \%$, biji pala sebanyak $52,83 \%$, daun sereh sebanyak $73,09 \%$, kayu manis sebanyak $52,28 \%$, dan merica putih sebanyak $46,86 \%$. Terlihat juga bahwa kontrol 1 dan 2 memiliki persentasi yang lebih rendah yaitu 45,01\% dan 38,42\%. Hal ini menunjukkan penambahan ekstrak rempah-rempah pada pisang goroho dapat meningkatkan aktivitas antioksidan 
tepung pisang goroho yang dapat berperan sebagai penangkal radikal bebas dari DPPH. Total aktivitas antioksidan berkorelasi positif dengan kandungan total senyawa fenolik tepung pisang goroho.

Mekanisme penangkal radikal bebas DPPH oleh antioksidan, yaitu berupa donasi proton kepada radikal. Senyawa-senyawa yang memungkinkan mendonasikan protonnya memiliki aktivitas penangkal radikal cukup kuat. Senyawa tersebut adalah golongan fenol, flavonoid tanin, senyawa yang memiliki banyak gugus sulfida dan alkaloid (Blois, 1958 dan Munim, 2003).

\section{Kesimpulan}

Berdasarkan hasil penelitian yang telah dilakukan, maka dapat disimpulkan bahwa tepung pisang goroho yang direndam dengan ekstrak rempah-rempah memiliki kandungan senyawa fenolik dan aktivitas antioksidan yang lebih tinggi dibanding tepung pisang yang tidak direndam dengan rempahrempah. Aktivitas antioksidan pisang goroho yang paling tinggi sampai terendah yaitu pada perendaman dengan ekstrak daun salam, kunyit, cengkeh dan andaliman, lengkuas, biji pala, daun sereh, kayu manis, jahe, dan merica putih.

\section{Daftar Pustaka}

Blois, M.S. Antioxidant Determinations by the use of a steble Free Radical, Nature. 1958, 181, 11991200

Conde, E., E. Cadahia, M.C. Garcia-Vallejo, B.F.D., Simon, dan J.R.G. Adrados. Low Molecular Weight PoLyphenol in Cork of Qoercus suber. J. Agric Food Chem. 1997, 45, 2695-2700.

Julkunen dan Titto, R. Phenolics Constituents in the Leaves of Northem Willows : Methods for the analysis of Certain Phenolics. J. Agric. Food Chem. 1985, 91, 571-577.

Kiay, N., E. Suryanto dan L. Mamahit. Efek Lama Perendaman Ekstrak Kalamansi (Citrus microcarpa) terhadap Aktivitas Antioksidan Tepung Pisang Goroho (Musa spp). Chem. Prog. 2011, 4, 27-33.

MSDS.2005. Natrium Bisulfit. Global Spill Control pty Ltd. Australia.

Munim, A. Antioxidative Compound From Crottalaria Sessiliflora. Biosci Biotech Biochem. 2003, $67,410-414$ 